\title{
KEDUDUKAN BARANG BUKTI SITAAN TINDAK PIDANA KORUPSI DI TINJAU DARI ASPEK KEPERDATAAN
}

\author{
Muhammad Juanda Sitorus
}

Universitas Riau, Indonesia,m.juanda_sitorus@gmail.com

\begin{abstract}
Position of Evidence Confiscated Corruption Crime in Review of Civil Aspects that in the mechanism of seizure of assets through criminal law, in principle the position of third parties is those parties other than the perpetrators / intellectuals of a corruption case, and related to confiscation aimed at assets that have been transferred ownership to a third party then if the assets are seized from a third party, the third party concerned must prove that the acquisition of the asset is based on the acquisition of good faith. Implementation of Asset Seizure from Transferred Corruption Results Ownership of Third Parties that seizure of objects related to a criminal act of corruption has become a legal requirement in order to uphold law and justice, so that the act of seizing assets resulting from a crime committed against assets belonging to the perpetrators of crime Upun assets that have switched ownership to third parties are very urgent, considering that aside from the need for evidence at the trial, the evidence that is confiscated is also intended to recover state financial losses resulting from corruptionthe criminal acts of corruption he did together with other actors.
\end{abstract}

Keywords: Position, Confiscated Evidence, Corruption Crime, Civil Aspect

\begin{abstract}
ABSTRAK
Kedudukan Barang Bukti Sitaan Tindak Pidana Korupsi di Tinjau dari Aspek Keperdataan bahwa didalam mekanisme perampasan aset melalui hukum pidana, pada prinsipnya kedudukan pihak ketiga adalah mereka pihak selain dari pada pihak pelaku/intelektual dari suatu perkara tindak pidana korupsi, dan berkaitan dengan penyitaan yang ditujukan pada aset yang telah dialihkan kepemilikannya kepada pihak ketiga maka jika aset yang dirampas dari pihak ketiga, pihak ketiga yang bersangkutan wajib membuktikan bahwa perolehannya atas aset tersebut dilandaskan pada perolehan yang beritikad baik.Pelaksanaan Penyitaan Aset dari Hasil Tindak Pidana Korupsi yang Telah Dialihkan Kepemilikannya Kepada Pihak Ketiga bahwa penyitaan terhadap benda yang berhubungan dengan suatu tindak pidana korupsi telah menjadi kebutuhan hukum dalam rangka menegakkan hukum dan keadilan, sehingga tindakan penyitaan aset hasil tindak pidana yang dilakukan terhadap aset milik pelaku kejahatan ataupun aset yang telah beralih kepemilikannya kepada pihak ketiga menjadi hal yang sangat urgen, mengingat selain untuk keperluan pembuktian di persidangan, barang bukti yang dilakukan penyitaan juga ditujukan untuk pemulihan kerugian keuangan negara yang ditimbulkan akibat dari tindak pidana korupsi.
\end{abstract}

Kata Kunci : Kedudukan, Barang Bukti Sitaan, Tindak Pidana Korupsi, Aspek Keperdataan 


\section{PENDAHULUAN}

Barang Sitaan dapat menjadi bagian

Penerimaan Negara Bukan Pajak

(PNBP), yakni telah diatur dalam

Peraturan Pemerintah No. 22 Tahun

1997 tanggal 7 Juli 1997 tentang Jenis

dan Penyetoran Penerimaan Negara

Bukan Pajak yakni menjelaskan poinpoin jenis-jenis penerimaan negara bukan pajak yang berlaku pada Kejaksaan Agung, diantaranya adalah sebagai berikut:

1. Penerimaan dari penjualan barang rampasan;

2. Penerimaan dari penjualan hasil sitaan/rampasan;

3. Penerimaan dari ganti rugi dan tindak pidana korupsi;

4. Penerimaan biaya perkara;

5. Penerimaan lain-lain, berupa uang temuan, hasil lelang barang temuan dan hasil penjualan barang;

6. Bukti yang tidak diambil oleh yang berhak; dan

7. Penerimaan denda

Dalam proses penanganan suatu perkara pada sistem peradilan, termasuk dalam sistem peradilan pidana, barang bukti menjadi salah satu komponen yang pasti melekat dan diperlukan untuk mengungkap kebenaran materiil mengenai duduk permasalahan suatu perkara / tindak pidana. Sistem peradilan pidana tidak mungkin dapat berjalan dan dapat mendekati kebenaran materiil tanpa hadirnya barang bukti. Para hamba hukum dalam hal ini, Penyidik, Penuntut Umum dan Hakim pasti akan menyertakan barang bukti menjadi bagian yang tak terpisahkan dalam pengungkapan dan penyelesaian suatu tindak pidana. Dengan kata lain, akan menjadi masalah besar apabila ada dugaan tindak pidana dan dilanjutkan proses peradilannya, namun tidak disertai dengan adanya barang bukti. Untuk memperoleh barang bukti dalam mengungkap suatu tindak pidana, berbagai strategi dan metode dapat dilakukan oleh Penyidik, antara lain melalui olah tempat kejadian perkara (TKP), penyerahan sukarela oleh para saksi atau pihak lain dan sebagainya. Apabila berbagai macam cara telah ditempuh oleh Penyidik, namun tetap tidak mendapatkan barang bukti, terkadang upaya paksa menjadi ikhtiar terakhir oleh Penyidik untuk 
mendapatkannya yakni melalui tindakan penyitaan.

Kejelian Penyidik dan Penuntut Umum untuk memilah dan memilih benda/barang mana yang akan dijadikan barang bukti dalam proses penyitaan dan prapenuntutan, juga bagaimana cara mengamankan barang bukti menjadi hal yang juga sangat dibutuhkan dalam proses penyitaan. Termasuk menjaga nilai (value) suatu barang bukti agar tidak menjadi under value. Hal demikian juga berlaku terhadap barang bukti/benda sitaan dan barang rampasan dalam penanganan tindak pidana korupsi dan tindak pidana pencucian uang.

Barang bukti sitaan yang disita oleh aparat merupakan serangkaian tindakan untuk mendukung dan mempermudah jalannya proses pemeriksaan. Penyitaan tersebut dilakukan karena dianggap bahwa barang bukti tersebut dapat mempermudah proses pembuktian suatu tindak pidana. Pengertian penyitaan itu sendiri dapat diartikan sebagai suatu penyitaan yang dilakukan terhadap barang bergerak ataupun tidak bergerak milik seseorang untuk mendapatkan bukti dalam proses peradilan pidana.
Menurut Darwin Prinst ${ }^{1}$ bahwa pengertian Penyitaan terhadap barang bukti sitaan yaitu :Suatu cara yang dilakukan oleh pejabat yang berwenang untuk menguasai sementara waktu barang-barang baik yang merupakan milik tersangka/ terdakwa ataupun bukan, tetapi berasal dari atau ada hubungannya dengan suatu tindak pidana dan berguna untuk pembuktian.

Ketentuan mengenai penyitaan terhadap barang bukti sitaan yang dilakukan dalam melakukan suatu kejahatan ataupun barang bukti sitaan yang merupakan hasil dari kejahatan tersebut, diatur dalam ketentuan KUHAP khususnya dalam Pasal 1 angka 16 tertulis bahwa :Penyitaan adalah serangkaian tindakan penyidik untuk mengambil alih atau menyimpan di bawah penguasaannya benda bergerak atau tidak bergerak, berwujud dan tidak berwujud untuk kepentingan pembuktian dalam penyelidikan, penuntutan dan peradilan.

Berdasarkan pengertian di atas, nampak bahwa penyitaan barang bukti sitaan dilakukan hanya dalam hal

\footnotetext{
${ }^{1}$ Darwan Prinst, Hukum Acara Pidana Dalam Praktik, djambatan, Jakarta, 1998, hal. 69
} 
kepentingan pembuktian, penuntutan dan peradilan, sesuatu benda atau barang dapat disita dan dikuasai oleh orang lain atau pihak lain untuk sementara waktu. Jadi penyitaan (beslagneming) merupakan cara yang dilakukan oleh pejabat berwenang untuk menguasai sementara waktui barang-barang bukti sitaan baik itu barang milik tersangka/ terdakwa ataupun barang bukti sitaan hasil kejahatan.

Selanjutnya harus dibedakan antara penyitaan terhadap barang bukti sitaan dan perampasan. Perampasan diartikan bahwa benda atau barang tersebut diambil alih dari pemiliknya dengan tujuan untuk mencabut status hak milik atas barang itu untuk kemudian digunakan bagi kepentingan negara, untuk dimusnahkan atau untuk di rusak hingga tidak dapat lagi dipergunakan.

Menurut Amiruddin bahwa perbedaan antara penyitaan dan perampasan yaitu : Penyitaan adalah bahwa untuk sementara milik seseorang dilepaskan dari pemiliknya untuk keperluan pembuktian dan lain daripada itu hak milik tidak terlepas dari si pemiliknya; akibat hukumnya adalah dapat dirampas atau dikembalikan kepada yang berhak. Sedangkan perampasan adalah hanya dapat dinyatakan oleh hakim dalam putusannya; akibat hukumnya adalah milik barang itu disampaikan atau diambil alih oleh negara. Dengan kata lain bahwa penyitaan harus mengandung makna bahwa penguasaan terhadap benda tersebut adalah bersifat sementara yang berarti bahwa kemudian apabila sudah tidak dipergunakan lagi, maka akan dikembalikan kepada yang berhak akan tetapi perampasan ini bukan untuk sementara melainkan pihak yang berwenang mencabut hak milik atas benda itu untuk selama-lamanya. ${ }^{2}$

$$
\text { Pada umumnya tindakan }
$$
penyitaan terhadap barang bukti dihubungkan dengan tindakan perampasan sebagai bentuk pidana tambahan dalam suatu proses peradilan pidana. Penyitaan sebagaimana telah ditentukan juga berhubungan dengan masalah barang bukti sebagai benda yang disita oleh negara dalam kepentingan penyidikan, penuntutan dan proses peradilan sebagaimana di atur dalam Pasal 39 KUHP :

\footnotetext{
2 Ratna Nurul Afiah, Barang Bukti Dalam Proses Pidana, Sinar Grafika, Jakarta, 2002, hal. 27
} 
1. Barang-barang kepunyaan terpidana yang diperoleh dari kejahatan atau yang sengaja dipergunakan untuk melakukan kejahatan, dapat dirampas.

2. Dalam hal pemidanaan karena kejahatan yang tidak dilakukan dengan sengaja atau karena pelanggaran, dapat juga dijatuhkan putusan perampasan berdasarkan hak-hak yang ditentukan dalam undang-undang.

3. Perampasan dapat dilakukan terhadap orang yang bersalah yang diserahkan kepada pemerintah, tetapi hanya atas barang-barang yang telah disita.

Menurut Andi Hamzah tentang barang bukti atau benda yang dapat disita yaitu : Barang-barang kepunyaan tersangka yang diperoleh karena kejahatan dan barang-barang yang dengan sengaja telah dipergunakan untuk melakukan kejahatan. $^{3}$

Di samping itu secara rinci mengenai benda yang dapat disita dalam rangka suatu penyidikan dan penuntutan diatur dalam Pasal 39 KUHAP

3 Andi Hamzah, Hukum Acara Pidana Indonesia, Arikha Media Cipta, Jakarta, 2014, hal. 112 ditentukan bahwa denda yang dapat dikenakan penyitaan adalah:

1. Benda atau tagihan tersangka atau terdakwa yang seluruh atau sebagian diduga diperoleh dari suatu tindak pidana atau sebagian hasil dari tindak pidana;

2. Benda yang telah dipergunakan secara langsung untuk melakukan tindak pidana atau untuk mempersiapkannya;

3. Benda yang dipergunakan untuk menghalang-halangi suatu proses penyelidikan tindak pidana;

4. Benda yang khusus dibuat atau diperuntukkan melakukan tindak pidana;

5. Benda lain yang mempunyai hubungan langsung dengan tindak pidana yang dilakukan.

Berdasarkan uraian di atas, nampak bahwa barang yang dapat disita yaitu benda yang dapat dianggap ataupun dapat dipakai untuk mengungkap dan mendapatkan kebenaran, juga secara langsung memperluas pejabat yang memiliki kewenangan dalam penyitaan.

Kecenderungan dalam penyitaan pada perkara Tindak Pidana Korupsi 
(selanjutnya disingkat TPK) dan/atau Tindak Pidana Pencucian Uang (selanjutnya disingkat TPPU), terdapat benda sitaan yang kemudian dijadikan barang bukti berupa harta kekayaan yang terdiri dari beragam aset bernilai ekonomi tinggi, seperti : kendaraan (motor / mobil mewah), tanah dan/atau bangunan, apartemen, lahan pertanian/peternakan, pabrik, Stasiun Pengisian Bahan Bakar Umum (SPBU) dan sebagainya hingga saat ini belum optimal dalam pengelolaannya. Namun bagaimana bila barang yang bukti yang disita tersebut sebahagian besar sahamnya adalah milik orang lain yang tidak ada terkait korupsi, seperti yang terjadi pada sekolah Indonesian Creative School (ICS) yang berada di Jalan Arifin Ahmad Pekanbaru. Di plang yang di tempel oleh Kejaksaan Negeri Bengkalis itu tertulis " Dalam Perkara Tindak Pidana Korupsi dan Tindak Pidana Pencucian Uang Pernyataan Modal Dan Penggunaan Keuangan PT. Bumi Laksamana Jaya Group ".

Sekolah yang berdiri sejak tahun 2009 ini terletak di jalan Arifin Ahmad tepatnya di seberang Pujasera Arifin Ahmad Pekanbaru, di sekolah ini menyediakan pendidikan untuk tingkatan SD, TK dan SMP. Sekolah ini juga banyak anak-anak pejabat di lingkungan Pemprov yang menitipkan buah hatinya untuk mengenyam pendidikan di sekolah tersebut. Seperti diketahui sebelumnya sekolah ini dikabarkan mendapat aliran dana dari PT Bumi Laksamana Jaya (BLJ) sebesar Rp. 30 miliar, yang mana dana tersebut seharusnya diperuntukan untuk pembangunan Pembangkit Tenaga Listrik Gas dan Uap (PLTGU) di desa Buruk Bakul kecamatan Bukit Batu, dan desa Balai Pungut kecamatan Pinggir kabupaten Bengkalis. PT. Kalta Citra Utama bekerja sama dengan PT Bumi Laksamana Jaya (BLJ) dalam Akta Perjanjian Kerjasama Nomor 15 tanggal 19 November 2012 tersebut PT Bumi Laksamana Jaya (BLJ) adalah Pihak Kedua sebagai pemilik modal investasi sebesar Rp.30.000.000.00,-(tiga puluh milyar rupiah) dan pihak pertama adalah pemilik tanah. Namun setelah gedung Indonesian Creative School (ICS) tersebut berdiri dan beroperasi, ternyata PT Bumi Laksamana Jaya (BLJ) melakukan tindak pidana korupsi, sehingga gedung ICS tersebut disita oleh Kejari Bengkalis dan atas peristiwa penyitaan tersebut, maka PT. Kalta Citra 
Utama dirugikan atas penyitaan yang dilakukan oleh Kejari Bengkalis.

\section{RUMUSAN MASALAH}

Berdasarkan latar belakang di atas maka masalah yang akan dijawab dalam penelitian Tesis ini adalah :

1. Bagaimanakah Kedudukan

Barang Bukti Sitaan Tindak

Pidana Korupsi di Tinjau dari Aspek Keperdataan?

2. Bagaimanakah Pelaksanaan

Penyitaan Aset dari Hasil Tindak

Pidana Korupsi yang Telah

Dialihkan Kepemilikannya

Kepada Pihak Ketiga?

\section{HASIL PEMBAHASAN}

\section{A. Kedudukan Barang Bukti Sitaan Tindak Pidana Korupsi di Tinjau dari Aspek Keperdataan}

Tindak pidana korupsi merupakan salah satu kejahatan non konvensional yang semakin populer dikalangan masyarakat. Dalam UndangUndang Nomor 31 Tahun 1999 tentang Pemberantasan Tindak Pidana Korupsi sebagaimana diubah dengan UndangUndang Nomor 20 Tahun 2001, Tindak pidana korupsi adalah Tindakan yang secara melawan hukum memperkaya diri sendiri atau orang lain atau suatu korporasi yang dapat menimbulkan kerugian keuangan Negara. ${ }^{4}$

Harta kekayaan hasil kejahatan yang dilakukan oleh koruptor sering sudah dialihkan hak kepemilikannya kepada pihak ketiga, untuk mengaburkan asal-usul kekayaan tersebut. Dengan demikian begitu besar aset negara yang dihasilkan dari tindak pidana korupsi yang digelapkan agar tidak terlacak oleh aparatur penegak hukum. Tentunya dengan melihat kondisi yang terjadi di Indonesia saat ini, dapat dirasakan bahwa perekonomian tidak berubah seperti yang kita harapkan. ${ }^{5}$

Dalam hal ini banyak modus penggelapan kekayaan negara dari hasil tindak pidana korupsi yang belum dapat ditanggulangi menggunakan mekanisme hukum yang ada. Mengingat sistem perundang-undangan yang tidak fleksibel dan selalu dituntut untuk dilakukan perubahan dan pembaharuan sesuai keadaan yang terjadi. Terjadi ironi

\footnotetext{
${ }^{4}$ Juni Sjafrien, Say No To Korupsi, Visimedia, Jakarta: 2012, hal.13

${ }^{5}$ Dedy Saputra, Pertanggungjawaban Pidana Terhadap Pelaku Tindak Pidana Korupsi Menerima Gratifikasi Dengan Sistem Pembalikan Beban Pembuktian, Jurnal Ilmu Hukum, Magister Ilmu Hukum UNRI, Volume 7 No. 1, Agustus 2017, hal. 4
} 
ketika pelaku tindak pidana korupsi menikmati hasil kejahatannya untuk kepentingan pribadi atau bahkan kepentingan bersama dengan pihak lainnya, namun secara hukum tidak dapat disentuh oleh perangkat hukum yang ada. Secara hukum ada beberapa metode yang memungkinkan digunakan oleh koruptor untuk menggelapkan harta kekayaan negara yakni melalui instrument hukum perdata yakni; perjanjian kerjasama penyertaan modal, jual beli, dan lainnya.

Praktik perjanjian kerjasama yang terjadi juga tidak terlepas dari resiko-resiko yang muncul yaitu tidak dipenuhinya unsur-unsur dalam perjanjian kerjasama yang telah dibuat oleh para pihak misalnya dalam suatu perjanjian kerjasama penyertaan modal dan bisa saja salah satu pihak melakukan tindakan-tindakan yang merugikan pihak lainnya. Kejujuran atau itikad baik dalam perjanjian kerjasama tersebut merupakan faktor yang penting sehingga para pihak yang beritikad baik akan mendapat perlindungan hukum secara wajar, sedangkan yang tidak beritikad baik tidak perlu mendapat perlindungan hukum. Umumnya dapat dikatakan, bahwa dalam pergaulan hidup ditengah- tengah masyarakat, pihak yang jujur atau beritikad baik haruslah dilindungi dan sebaliknya pihak yang tidak jujur atau tidak beritikad baik patut merasakan akibat dari ketidakjujurannya itu. ${ }^{6}$

Walaupun itikad baik menjadi asas penting dalam hukum kontrak di berbagai sistem hukum, tetapi asas itikad baik tersebut masih menimbulkan sejumlah permasalahan terutama yang berkaitan dengan keabstrakan makna itikad baik. $^{7}$

Kejujuran atau itikad baik, dapat dilihat dalam dua macam, yaitu pada waktu mulai berlakunya suatu perhubungan hukum atau pada waktu pelaksanaan hak-hak dan kewajibankewajiban yang termaktub dalam perhubungan hukum itu. Kejujuran pada waktu mulainya dalam hati sanubari yang bersangkutan, bahwa syarat-syarat yang diperlukan bagi mulai berlakunya perhubungan hukum itu sudah dipenuhi semua, sedang kemudian ternyata bahwa ada syarat yang tidak terpenuhi. Dalam hal yang demikian itu, bagi pihak yang jujur dianggap seolah-olah syarat-syarat

${ }^{6}$ Agus Yudha Hermoko, Hukum Perjanjian: Asas Proporsionalitas Dalam Kontrak Komersial, Kencana, Jakarta, 2012, hal. 14

${ }^{7}$ Salim H.S, Hukum Kontrak: Teori dan Teknik Penyusunan Kontrak, Sinar Grafika, Jakarta, 2009, hal. 31 
tersebut dipenuhi semua, atau dengan salah satu pihak maupun secara kata lain yang jujur tidak boleh keseluruhan para pihak dari kejahatan dirugikan sebagai akibat tidak dapat dikenakan sanksi pidana. Seperti terpenuhinya syarat termaksud di dalam halnya dengan perjanjian kerjasama perjanjian itu.

Dalam Kitab Undang-undang penyertaan modal yang dilakukan PT Bumi Laksamana Jaya (BLJ) dengan PT. Hukum Perdata, ketentuan mengenai itikad baik, khususnya yang berhubungan dengan pelaksanaan perjanjian terdapat dalam Pasal 1338 ayat (3) yang menetapkan bahwa semua perjanjian harus dilaksanakan dengan itikad baik. Ini berarti, bahwa setiap pihak yang membuat perjanjian tersebut dibuat dengan disertai oleh itikad baik, dalam hal ini termasuk perjanjian kerjasama penyertaan modal usaha. Sehingga dengan demikian, sepanjang terjadinya perjanjian kerjasama yang tidak wajar dilakukan, dengan harga yang wajar dan diketahui atau patut diduga bahwa objek yang diperjanjikan tersebut adalah objek "terang" dan bukan hasil dari suatu kejahatan (korupsi), dan para pihak tidak menarik keuntungan dari peristiwa perjanjian itu, maka para pihak dapat bisa terhindar dari ancaman pidana.

Mengingat terjadinya perjanjian kerjasama yang didasari oleh adanya unsur tindak pidana yang dilakukan oleh

Kalta Citra Utama. Perjanjian tersebut adalah perjanjian melakukan kerjasama pembangunan gedung sekolah "Indonesian Creative School (ICS)" yang terletak J1. Arifin Ahmad Pekanbaru. Dalam pelaksanaan pembangunan gedung sekolah tersebut PT Bumi Laksamana Jaya (BLJ) menyuntikkan dana sebesar Rp. 30 miliar, untuk pembangunan gedung sekolah tersebut dan pelaksanaannya. Padahal diketahui berdasarkan penyidikan Kejaksaan Negeri Bengkalis, bahwa aliran dana tersebut berasal dari korupsi proyek pembangunan Pembangkit Tenaga Listrik Gas dan Uap (PLTGU) di desa Buruk Bakul kecamatan Bukit Batu, dan di Desa Balai Pungut Kecamatan Pinggir Kabupaten Bengkalis dan akibat dari tindak pidana korupsi yang dilakukan maka sampai saat ini gedung sekolah Indonesian Creative School (ICS) menjadi barang sitaan Kejaksaan Negeri Bengkalis. 
Apabila melihat keberadaan tersebut berdiri dan beroperasi, ternyata gedung sekolah Indonesian Creative PT Bumi Laksamana Jaya (BLJ) School (ICS) yang berdiri sejak tahun melakukan tindak pidana korupsi, 2009 yang terletak di jalan Arifin sehingga gedung ICS tersebut disita oleh Ahmad ini, bahwa sekolah ini Kejari Bengkalis dan atas peristiwa menyediakan pendidikan untuk tingkatan SD, TK dan SMP. Sekolah ini juga banyak anak-anak pejabat di lingkungan Pemprov yang menitipkan buah hatinya untuk mengenyam pendidikan di sekolah tersebut. Seperti diketahui sebelumnya sekolah ini dikabarkan mendapat aliran dana dari PT Bumi Laksamana Jaya (BLJ) sebesar Rp. 30 miliar, yang mana dana tersebut seharusnya diperuntukan untuk pembangunan Pembangkit Tenaga Listrik Gas dan Uap (PLTGU) di desa Buruk Bakul kecamatan Bukit Batu, dan desa Balai Pungut kecamatan Pinggir kabupaten Bengkalis. PT. Kalta Citra Utama bekerja sama dengan PT Bumi Laksamana Jaya (BLJ) dalam Akta Perjanjian Kerjasama Nomor 15 tanggal 19 November 2012 tersebut PT Bumi Laksamana Jaya (BLJ) adalah Pihak Kedua sebagai pemilik modal investasi sebesar Rp.30.000.000.00,-(tiga puluh milyar rupiah) dan pihak pertama adalah pemilik tanah. Namun setelah gedung Indonesian Creative School (ICS) penyitaan tersebut, maka PT. Kalta Citra Utama dirugikan atas penyitaan yang dilakukan oleh Kejari Bengkalis.

\section{B. Pelaksanaan Penyitaan Aset dari Hasil Tindak Pidana Korupsi yang Telah Dialihkan Kepemilikannya Kepada Pihak Ketiga}

Perampasan aset terhadap pelaku tindak pidana korupsi didasarkan atas pasal 18 huruf (a) Undang-Undang tindak pidana korupsi yang menyatakan :"perampasan barang bergerak yang berwujud atau tidak berwujud atau barang tidak bergerak yang digunakan untuk atau yang diperoleh dari tindak pidana korupsi, termasuk perusahaan milik terpidana dimana tindak pidana korupsi dilakukan, begitu pula harga dari barang yang menggantikan barang-barang tersebut".

Perampasan menurut Pasal 38 angka 5 UU Tipikor tersebut merupakan pengecualian dari Pasal 77 KUHP, yang menyatakan bahwa "hak menuntut hilang karena meninggalnya si 
tersangka”. Pengecualian atau penyimpanan ini dibenarkan berdasarkan Pasal 103 KUHP yang menganut asas lex specialis derogat lex generalis, akan tetapi pembenaran tersebut sejauhmana apabila diantara kedua Undang-undang tersebut mengatur suatu materiele daad yang sama, makalex specialis yang harus diberlakukan. Pasal 38 KUHAP telah mengatur bahwa seorang penyidik dapat melakukan penyitaan atas dasar surat izin dari Pengadilan Negeri setempat (atau tanpa surat izin dari hakim apabila dalam situasi yang mendesak dan hanya terhadap benda bergerak namun setelah penyitaan wajib memberikan laporan penyidik kepada Pengadilan Negeri setempat).

Dalam hal perampasan harta kekayaan yang telah dialihkan oleh pihak ketiga tentunya dilakukan berdasarkan apa yang telah dijelaskan diatas bahwa haruslah ada putusan pengadilan yang telah memiliki kekuatan tetap yang menyatakan terdakwa terbukti telah melakukan tindak pidana korupsi dan dinyatakan sebagai terpidana dengan dikenakan tuntutan untuk dirampas harta kekayaanya yang merupakan hasil kejahatan dari tindak pidana korupsi. Dan jika harta kekayaan telah dipindahtangankan atau dikuasai oleh pihak lain maka secara langsung atau tidak langsung tindakan perampasan dilakukan terhadap aset tersebut tanpa melihat keberadaan harta tersebut berada dalam penguasaan siapa, dan berdasarkan perlindungan hukum pada Pasal 19 UU TIPIKOR, diberikan upaya terhadap pihak-pihak yang mersa dirugikan atas tindakan perampasan aset tersebut untuk melakukan keberatan dengan melakukan pembuktian terbalik. Terhadap aset yang telah dialihkan kepada pihak ketiga oleh pelaku tindak pidana korupsi, dengan tujuan agar aset tersebut tidak dapat diketahui oleh aparatur penegak hukum sehingga kejahatan tidak dapat terungkap. Dengan ini ada upaya yang dapat dilakukan pihak aparatur penegak hukum untuk melakukan tindakn dari modus-modus yang secara umum maupun secara khusus yang dapat dilakukan oleh pelaku tindak pidana korupsi, diantaranya adalah; traksaksitransaksi properti dapat dimanipulasi untuk menggunakan hasil-hasil modal yang tampak untuk menyamarkan danadana gelap tersebut. 
Berdasarkan pada modus tersebut maka aparatur penegak hukum yang diberi kewenangan dalam melakukan penelusuran atau penyidikan untuk mendapat pembuktikan dengan melakukan tindakan; pengeledahan atas tersangka dan tanah bangunan terkait dapat mengenali dokumen-dokumen atau referensi-referensi atas properti pertanahan, seperti catatan harian tersangka, wawancara kepada pihak yang dibutuhkan, identifikasi setiap transaksi termasuk terhadap barangbarang berharga. Berdasarkan kenyataan dalam praktek upaya-upaya tersebut dalam dilihat beberapa kelemahan atau bahkan kesulitan yang ada sebagai penghambat atau penghalang dalam rangka mekanisme perampasan aset untuk pemulihan aset dari terjadinya tindak pidana.

Perampasan aset yang berasal dari tindak pidana melalui jalur keperdataan tidak serta merta melanggar asas praduga tak bersalah atau priviliged against self-incrimination sekalipun tidak perlu dibuktikan kesalahan tersangka/terdakwa. Sedangkan perampasan aset tindak pidana melalui jalur kepidanaan harus terlebih dulu dibuktikan kesalahan orang yang menguasai aset tersebut sampai memperoleh putusan yang memiliki kekuatan hukum tetap; jika tidak demikian perampasan aset tindak pidana melanggar asas praduga tak bersalah.

Pengalihan aset yang diperoleh dari hasil kejahatan lazim dilakukan dalam setiap tindak kejahatan yang bertujuan agar harta benda tersebut diketahui keberadaannya oleh aparatur penegak hukum. Lazimnya pelaku tindak pidana korupsi melakukan pengalihan aset agar tidak terdeteksi oleh para penegak hukum yang bertujuan untuk menutupi aset hasil kejahatan. Modus yang digunakan biasanya dengan memanipulasi transaksitransaksi peralihan hak dengan tujuan untuk menyamarkan dana-dana gelap hasil kejahatan tersebut. Dalam perkara tindak pidana korupsi, tentunya sangat berkaitan erat dengan adanya kerugian negara yang berkorelasi dengan harta kekayaan negara yang diselewengkan oleh pelakunya.

Upaya pengembalian hasil tindak pidana korupsi, terdapat kemungkinan terjadi suatu kegagalan atau kekurangan. Berdasarkan kenyataan dalam praktek upaya-upaya tersebut dapat dilihat beberapa kelemahan atau bahkan 
kesulitan yang ada sebagai penghambat atau penghalang dalam rangka perampasan aset untuk pemulihan aset (recovery aset) dari terjadinya tindak pidana korupsi. Permasalahan tersebut diantaranya adalah dalam hal pemenuhan uang pengganti oleh terpidana yang tidak mempunyai itikad untuk membayarnya, terkendala disebabkan harta-harta tersebut sudah beralih atas nama pihak ketiga. Dimana perikatan antara pelaku dengan pihak ketiga dapat terjadi dengan didasarkan asas-asas hukum perdata yang memang harus dinilai memiliki kekuatan hukum yang sah. Salah satu cara pengalihan kepada pihak ketiga dengan berbagai modus tersebut juga tidak dapat dipungkiri aset yang diduga dari hasil korupsi tersebut telah dilakukan jual beli oleh pelaku tindak pidana kepada pihak ketiga dengan akta pejabat yang berwenang. Jika dilihat dari proses dan syarat untuk melakukan jual beli tersebut tidak ada yang bermasalah atau melanggar ketentuan hukum, syarat untuk membuat peralihan hak tersebut telah terpenuhi, tetapi yang jadi permasalahan setelah proses jual beli dilakukan atau ditandai dengan adanya penyerahan (levering) yaitu perpindahan antara pemilik yang satu kepada pemilik lainya secara sah, obyek yaitu dalam hal ini tanah, rumah atau aset yang diperjanjikan akan diserahkan disita oleh negara karena diduga diperoleh dari hasil tindak pidana korupsi yang dilakukan oleh pihak penjual.

Dalam suatu proses perkara pidana, khususnya perkara tindak pidana korupsi, tindakan penyitaan terhadap aset yang diduga merupakan hasil dari tindak pidana korupsi menjadi hal yang sangat urgen, mengingat selain untuk keperluan pembuktian di persidangan, barang bukti yang dilakukan penyitaan juga ditujukan untuk pengembalian kerugian keuangan negara yang ditimbulkan akibat dari korupsi. Sehingga dengan demikian, penyitaan menjadi suatu awal yang penting dalam tahapan proses perkara korupsi dari tingkat penyelidikan, penyidikan, penuntutan dan sidang di pengadilan. Perlu kehati-hatian dalam menyita barang atau benda yang digunakan dalam suatu perkara pidana. Harus dipastikan bahwa antara benda yang disita dengan pelaku tindak pidana itu ada korelasinya yang betul-betul akurat. Karena apabila penyidik tidak dapat menjelaskan hubungan dari barang yang 
akan disita dengan suatu tindak pidana yang disangkakan maka izin penyitaan dapat ditolak oleh Ketua Pengadilan Negeri setempat.

Kebendaan menurut bentuknya, dibedakan menjadi benda bertubuh dan tak bertubuh. Sedangkan menurut sifatnya, benda dibedakan menjadi benda bergerak yaitu yang dihabiskan dan tidak dapat dihabiskan, serta benda tidak bergerak. Hal ini sesuai dengan pengertian harta kekayaan yang diatur dalam Undang-Undang Nomor 8 tahun 2010 tentang Pencegahan dan Pemberantasan Tindak Pidana Pencucian Uang, yaitu; "Harta kekayaan adalah semua benda bergerak atau benda tidak bergerak, baik yang berwujud maupun yang tidak berwujud, yang diperoleh baik secara langsung maupun tidak langsung".

Terhadap perampasan tersebut dapat dilakukan upaya pengembalian apabila ada kepentingan-kepentingan/ hak-hak dari pihak ketiga yang dirugikan, terkait dengan aset yang dirampas tersebut pihak ketiga dapat melakukan pembuktian bahwa kepentingan/ hak tersebut benar adanya dan tidak merupakan bagian dari suatu tindak pidana korupsi atau kepunyaan terpidana (Pasal 19 ayat (1) UU TIPIKOR). Dengan ini pihak ketiga dapat mengajukan surat keberatan kepada pengadilan yang bersangkutan, dalam waktu paling lambat 2 (dua) bulan setelah putusan pengadilan ditetapkan disidang terbuka untuk umum (Pasal 19 ayat (2) UU TIPIKOR). Dalam hal perampasan harta kekayaan yang telah dialihkan oleh pihak ketiga tentunya dilakukan berdasarkan apa yang telah dijelaskan di atas bahwa haruslah ada putusan pengadilan yang telah memiliki kekuatan hukum tetap yang menyatakan bahwa terdakwa terbukti telah melakukan tindak pidana korupsi dan dinyatakan sebagai terpidana dengan dikenakan tuntutan untuk dirampas harta kekayaannya yang merupakan hasil kejahatan dari tindak pidana korupsi. Dan jika harta kejahatan tersebut telah berpindah tangan atau dikuasai oleh pihak lain maka secara langsung atau tidak langsung tindakan perampasan dilakukan terhadap aset tersebut tanpa melihat keberadaan harta tersebut berada dalam penguasaan siapa, dan berdasarkan perlindungan hukum pada Pasal 19 UU Tipikor, diberikan upaya terhadap pihakpihak yang merasa dirugikan atas tindakan perampasan aset 
tersebut untuk melakukan keberatan dengan melakukan pembuktian terbalik. Maka pada posisi ini tentu peranan mekanisme pembuktian terbalik sangat dominan dalam mekanisme perampasan aset yang dimana aset tersebut dikuasai atau berada pada pihak ketiga.

Ketentuan dalam Pasal 37 UndangUndang Nomor 31 Tahun 1999 tentang Pemberantasan Tindak Pidana Korupsi tersebut merupakan suatu penyimpangan dari Pasal 66 Kitab Undang-undang Hukum Acara Pidana yang menyebutkan bahwa tersangka atau terdakwa tidak dibebani kewajiban pembuktian. Apabila terdakwa dapat membuktikan hal tersebut, tidak berarti ia tidak terbukti melakukan korupsi, sebab penuntut umum masih tetap berkewajiban untuk membuktikan dakwaannya. Pembuktian terbalik yang bersifat terbatas sebagaimana tersebut di atas, hanya terjadi di sidang pengadilan. Perampasan aset tidak dimaksudkan untuk menyita harta kekayaan milik orang yang tidak bersalah atau beritikad baik. Perampasan aset haruslah dimaksudkan untuk menguasai keuntungan yang diperoleh dari tindak pidana sehingga tindakan tersebut juga merupakan upaya pencegahan terhadap kemungkinan adanya perbuatan berlanjut dari suatu tindak pidana atau untuk melakukan tindak pidana lain dimasa yang akan datang.

Dalam pelaksanaannya harus ada jaminan bahwa seseorang yang tidak bersalah atau beritikad baik dikecualikan dari ketentuan perampasan aset selama ia dapat menunjukkan bukti-bukti yang cukup tentang ketidakterlibatannya atau ketidaktahuannya terhadap kejahatan yang terkait dengan harta kekayaan.

Perampasan pidana terhadap aset hasil tindak pidana korupsi, merupakan sebuah sanksi pidana yang dijatuhkan berdasarkan putusan pengadilan pidana terhadap perkara tindak pidana korupsi yang telah diputuskan oleh hakim berdasarkan tuntutan yang diajukan oleh jaksa penuntut umum pada sidang pengadilan pidana terhadap aset yang dikuasai oleh pihak terdakwa yang diyakini merupakan hasil tindak pidana yang terkait. Dengan melihat pada perkara tindak pidana korupsi itu sendiri, merupakan tindak pidana yang dalam penanganan perkaranya dilakukan secara khusus yang telah diberikan mekanismenya melalui sistem peradilan pidana berdasarkan Undang-undang yaitu Pengadilan Tindak Pidana Korupsi 
yang merupakan pengadilan yang khusus menangani perkara korupsi.

Perampasan Pidana tersebut merupakan sistem yang didasari atas unsur obyektif, yang dalam hal ini kewenangan jaksa harus membuktikan bahwa aset yang dimaksud merupakan suatu hasil atau sarananya kejahatan yang telah selesai atau dalam proses kejadiannya. Pada kondisi tertentu Jaksa dapat berdasarkan nilai-nilai norma, yang memungkinkan untuk dirampas dari nilai manfaat bagi pelaku dari kejahatan, tanpa membuktikan hubungan antara kejahatan dan objek aset tersebut. Perampasan aset pidana tunduk pada semua perlindungan prosedural konstitusional dan peraturan yang tersedia di bawah naungan hukum pidana.

\section{KESIMPULAN}

a. Kedudukan Barang Bukti Sitaan Tindak Pidana Korupsi di Tinjau dari Aspek Keperdataan bahwa didalam mekanisme perampasan aset melalui hukum pidana, pada prinsipnya kedudukan pihak ketiga adalah mereka pihak selain dari pada pihak pelaku/intelektual dari suatu perkara tindak pidana korupsi, dan berkaitan dengan penyitaan yang ditujukan pada aset yang telah dialihkan kepemilikannya kepada pihak ketiga maka jika aset yang dirampas dari pihak ketiga, pihak ketiga yang bersangkutan wajib membuktikan bahwa perolehannya atas aset tersebut dilandaskan pada perolehan yang beritikad baik

b. Pelaksanaan Penyitaan Aset dari Hasil Tindak Pidana Korupsi yang Telah Dialihkan Kepemilikannya Kepada Pihak Ketiga bahwa penyitaan terhadap benda yang berhubungan dengan suatu tindak pidana korupsi telah menjadi kebutuhan hukum dalam rangka menegakkan hukum dan keadilan, sehingga tindakan penyitaan aset hasil tindak pidana yang dilakukan terhadap aset milik pelaku kejahatan ataupun aset yang telah beralih kepemilikannya kepada pihak ketiga menjadi hal yang sangat urgen, mengingat selain untuk keperluan pembuktian di persidangan, barang bukti yang 
dilakukan penyitaan juga ditujukan untuk pemulihan kerugian keuangan negara yang ditimbulkan akibat dari tindak pidana korupsi.

\section{DAFTAR KEPUSTAKAAN}

\section{Buku-buku}

Agus Yudha Hermoko, Hukum Perjanjian: Asas Proporsionalitas Dalam Kontrak Komersial, Kencana, Jakarta, 2012

Andi Hamzah, Hukum Acara Pidana Indonesia, Arikha Media Cipta, Jakarta, 2014

Dedy Saputra, Pertanggungjawaban Pidana Terhadap Pelaku Tindak Pidana Korupsi Menerima Gratifikasi Dengan Sistem Pembalikan Beban Pembuktian, Jurnal Ilmu Hukum, Magister Ilmu Hukum UNRI, Volume 7 No. 1, Agustus 2017

Darwan Prinst, Hukum Acara Pidana Dalam Praktik, djambatan, Jakarta, 1998

Juni Sjafrien, Say No To Korupsi, Visimedia, Jakarta: 2012

Ratna Nurul Afiah, Barang Bukti Dalam Proses Pidana, Sinar Grafika, Jakarta, 2002

Salim H.S, Hukum Kontrak: Teori dan Teknik Penyusunan Kontrak, Sinar Grafika, Jakarta, 2009

\section{Peraturan Perundang-Undangan}

UUD Negara Republik Indonesia Tahun 1945

Undang-Undang No. 20 Tahun 2001 Tentang Tipikor

Undang-Undang Republik Indonesia Nomor 8 Tahun 2010 Tentang Pencegahan dan Pemberantasan Tindak Pidana Pencucian Uang

Kitab Undang-Undang Hukum Pidana dan Acara Pidana 